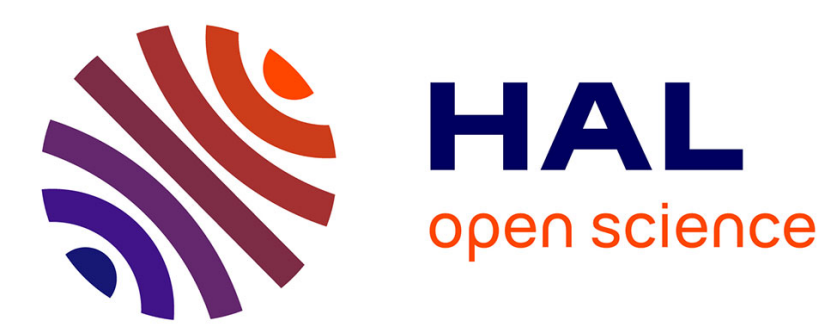

\title{
Direct impacts of recent climate warming on insect populations
}

\author{
Christelle Robinet, Alain Roques
}

\section{To cite this version:}

Christelle Robinet, Alain Roques. Direct impacts of recent climate warming on insect populations. Integrative Zoology, 2010, 5 (2), pp.132-142. 10.1111/j.1749-4877.2010.00196.x . hal-02667554

\section{HAL Id: hal-02667554 https://hal.inrae.fr/hal-02667554}

Submitted on 31 May 2020

HAL is a multi-disciplinary open access archive for the deposit and dissemination of scientific research documents, whether they are published or not. The documents may come from teaching and research institutions in France or abroad, or from public or private research centers.
L'archive ouverte pluridisciplinaire HAL, est destinée au dépôt et à la diffusion de documents scientifiques de niveau recherche, publiés ou non, émanant des établissements d'enseignement et de recherche français ou étrangers, des laboratoires publics ou privés. 


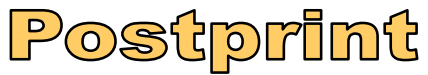

Version définitive du manuscrit publié dans / Final version of the manuscript published in : Integrative Zoology. 2010, 5(2), 132-142

doi: 10.1111/j.1749-4877.2010.00196.x

\title{
REVIEW
}

\section{Direct impacts of recent climate warming on insect populations}

Christelle ROBINET and Alain ROQUES

National Institute for Agricultural Reasearch, INRA UR633, Orléans, France

Running title: Insects and climate change

Authors running head: C. Robinet and A. Roques

Correspondence: Christelle Robinet, INRA Zoologie Forestière, 2163 Avenue de la Pomme de Pin, B.P. 20619 Ardon, 45166 Olivet cedex, France.

Email: robinet@orleans.inra.fr

\begin{abstract}
Effects of recent climate change have already been detected in many species, and, in particular, in insects. The present paper reviews the key impacts of global warming on insect development and dispersal. The effects of climate change appear to be much more complex than a simple linear response to an average increase in temperature. They can differ between seasons and bioclimatic regions. Earlier flight periods, enhanced winter survival and acceleration of development rates are the major insect responses. Differential response of insects and hosts to warming up might also lead to disruption of their phenological synchrony, but adaptive genetic processes are likely to quickly restore this synchrony. In a number of cases, warming results in removing or relocating the barriers that limit present species' ranges. It is also likely to facilitate the establishment and spread of invasive alien species. Finally, knowledge gaps are identified and future research interests are suggested.
\end{abstract}

Key words: adaptation, alien species, climate warming, phenology, range distribution. 


\section{INTRODUCTION}

Climate change involves simultaneous and complex changes of many environmental variables, but primarily air temperature (Trenberth et al. 2007). Mean global temperature has increased by approximately $1{ }^{\circ} \mathrm{C}$ since the pre-industrial era in Europe, with an acceleration during the past decades where 8 out of the 10 years between 1996 and 2007 were among the warmest years since 1850 (EEA 2008). Simultaneously, concentration of $\mathrm{CO}_{2}$ has increased by $30 \%$ from pre-industrial concentrations and is still rising. Based on various climate scenarios, the mean global temperature could increase by $1.8-4.0{ }^{\circ} \mathrm{C}$ for the period 2090 to 2099 relative to 1980 to 1999 (Meehl et al. 2007). Simultaneous changes in rainfall regimes and in frequency of extreme climatic events are also predicted.

Climatic parameters are known to have a direct effect on insect population dynamics through the modulation of survival, development rates, fecundity and dispersal (Messenger 1959; Andrewartha \& Birch 1984). Long-term data recorded in China over more than 1000 years was recently analyzed and it was revealed that locust outbreaks are closely associated with drought/flood frequencies and low temperature (Stige et al. 2007; Zhang et al. 2009). Indirect climatic effects via hosts, competitors and natural enemies have also been shown (Price et al. 1980; Herms \& Mattson 1992). The ongoing climate change is thus likely to induce significant responses from insect species. Signs of such responses have already been detected in recent years (Ayres \& Lombardero 2000; Hughes 2000; Harrington et al. 2001; Bale et al. 2002; Hill et al. 2002; Crozier 2003; Parmesan \& Yohe 2003; Battisti et al. 2005; Parmesan 2006; Menéndez 2007; Battisti 2008; Netherer \& Schopf 2010). According to the Intergovernmental Panel on Climate Change (IPCC), if conditions change beyond the tolerances of species, they might respond by shifting the timing of life-cycle events, shifting range boundaries or the density of individuals, changing morphology, reproduction or genetics, or go extinct (Rosenzweig et al. 2007). Although quantitative changes in a number of factors such as humidity, intensity and periodicity of rainfall, solar radiation, elevated $\mathrm{CO}_{2}, \mathrm{O}_{3}$ and ultraviolet light levels could be involved (Hunter 2001; Newman 2005; Stireman et al. 
2005; Asshoff \& Hättenschwiler 2006), most of these published studies essentially document the effects of increasing temperatures. Insects are essentially ectothermic organisms with their physiological processes displaying a high degree of sensitivity to ambient temperatures (Beck 1983). Therefore, they are likely to respond very quickly to an increase in temperature (Logan et al. 2003). Temperature thresholds often delimit one or more boundaries of a species' geographic range (Andrewartha \& Birch 1984). For example, as climatic isotherms have moved northwards $120 \mathrm{~km}$ on the average during the past century, $63 \%$ of the non-migratory European butterflies have extended their distribution by 35-240 km northwards (Parmesan et al. 1999). The 4th IPCC report mentioned the advanced emergence of butterflies, the extinction of some species, the increase in egg-laying for other species, genetically-based changes in morphology and other life-history traits, the expansion of damaging forest insects such as bark beetles in the USA and pine processionary moths in Europe, but also changes in the range of vector-borne diseases (Rosenzweig et al. 2007). Climate warming appears to have an increasingly important role in triggering increases in population abundance of native species (DeLucia et al. 2008), but also in facilitating the establishment and further spread of introduced alien species (Walther et al. 2009). Such changes are particularly obvious at higher altitudes and latitudes, and might result in a larger impact of herbivores (Wolf et al. 2008). However, the data accumulated so far suggest that the effect of climate change is much more complex than a simple, linear response to an average increase in temperature, and it is likely to differ between regions (Walther et al. 2002; Hickling et al. 2006; Deutsch et al. 2008). Moreover, Musolin et al. (2010) point out that insect responses to global warming are likely species-specific (or even population-specific) in nature (e.g. changes in distribution, phenology, abundance, population structure and dynamics), magnitude (from organisms to local and global communities) and strength (from undetectable or no responses to dramatic) (Bale et al. 2002; Parmesan 2007). Even within the same species or population, responses can differ, and sometimes be opposite, for different life-history traits as well as between seasons and bioclimatic regions (Battisti et al. 2006; Musolin et al. 2010; Robinet et al. 2010). Thus, the 
entire life cycle of species should generally be taken into account to determine the overall disturbance (Visser \& Both 2005). Therefore, even if some preliminary generalizations have been attempted about insect responses to global warming (e.g. about range modifications or phenological adaptations; Walther et al. 2001; Hickling et al. 2006; Parmesan 2007; Lawler et al. 2009), the effects of a future increase in temperature on insect communities are not so easy to predict (Helmuth 2009). Moreover, global warming simultaneously affects all the associated organisms (host plants, competitors, natural enemies, mutualists and symbionts), resulting in complex cascading effects on insect populations (Ayres \& Lombardero 2000; Walther et al. 2002; Rouault et al. 2006; Hance et al. 2007; Bidart-Bouzat \& Imeh-Nathaniel 2008; Netherer \& Schopf 2010).

In this paper, we intend to present the major patterns of insect responses to the recent increase in temperatures, during the past few decades, considering the direct impacts of global warming on insect development and dispersal. We will finally suggest key knowledge gaps and future research interests.

\section{EARLIER FLIGHTS AND ACCELERATION OF DEVELOPMENT RATES}

In organisms for which population dynamics is mainly controlled by temperature, positive direct responses to an increase in temperature are expected as long as the stage-specific thresholds for development are not exceeded. Therefore, development rates are likely to be sped up. A first sign is an earlier occurrence of spring flights in insect species from temperate countries. For more than $70 \%$ of the butterfly species examined, the first flight has recently advanced in the UK (Roy \& Sparks 2000), Spain (Stefanescu et al. 2003) and California (Forister \& Shapiro 2003). In California, global warming (warmer and drier winters) explained $85 \%$ of variation in the first flight date. More generally, Harrington et al. (2007) predict that the first aphid occurrence in Europe will advance by 1 day, on the average, every 4 years under classical climate change scenarios for the future. Similarly, butterfly flight is predicted to occur $2-10$ days earlier in the UK for every $1{ }^{\circ} \mathrm{C}$ increase (Roy \& Sparks 2000). 
In north-western North America, warmer temperatures have halved the time required to reproduce for the spruce beetle, Dendroctonus rufipennis Kirby, and have contributed to unprecedented damage to spruce forests (Berg et al. 2006). Polyvoltine species might profit as a result of this acceleration in cycle completion to produce one or more additional generations per year (Virtanen \& Neuvonen 1999; Ayres \& Lombardero 2000; Kiritani 2006; Gomi et al. 2007; Jönsson et al. 2009). Such processes have been observed in a number of insect groups, such as butterflies, bees, dragonflies and damselflies, flies and beetles (Gordo \& Sanz 2005). For example, the life cycle, life-history traits and, hence, the spread of the invasive fall webworm, Hyphantria cunea (Drury), have been affected by recent climate change in Japan. The moth recently expanded its range, mainly towards the north of the country. This spread coincided with a shift from a bivoltine to a trivoltine life-cycle in at least a part of the range, together with significant changes in the length of the critical photoperiod for diapause induction (Gomi et al. 2007). A damselfly Ischnura pumilio (Charpentier), which was trivoltine in the southern part of its range in Europe but univoltine or semivoltine in the northern part, also tends to become more and more bivoltine in the latter range (Ott 2008). Similarly, the European spruce bark beetle, Ips typographus (L.), is changing voltinism in European mountain forests as a consequence of the disproportionately large warming at high elevations, and it might, therefore, have unprecedented outbreaks (Lange et al. 2006). For the future, models from Harrington et al. (2001) predict that an increase of winter and spring temperatures by $2{ }^{\circ} \mathrm{C}$ would allow some aphid species to produce $4-5$ additional generations per year.

\section{NEGATIVE EFFECTS ON HOST-INSECT PHENOLOGICAL SYNCHRONY?}

Although an accelerated development potentially gives an important benefit for the insect species, this change in phenology might have some serious drawbacks. In insect herbivores, phenological synchrony between host plant development and insect life stages is often essential for developmental success (Van Asch \& Visser 2007). It is especially true for host-specific insects 
overwintering as eggs, such as a number of lepidopterans defoliating trees and shrubs, which need neonates hatching in spring to be precisely timed with plant budburst. Because the lower temperature thresholds for resuming development following winter might differ between the host plant and the associated insect, an increase in temperature is likely to affect their respective growth rates differently. Such a mismatch between vegetative budburst and hatching of larvae has already been observed over the past 2 decades for the system oak-winter moth, Opheroptera brumata (L.), where the egg hatch date has advanced more than the bud burst date of pedunculate oak (Visser \& Both 2005). Similar observations have been made for sycamore and its associated aphid, Drepanosiphum platanoides Koch. (Dixon 2003). Winter and spring temperatures unusually warm for the period 1989-1991 might also have disrupted the strict synchrony previously existing between hatching of larch budmoth larvae, Zeiraphera diniana Guénée, and larch foliage availability (Esper et al. 2007). This could be a major reason of the unexpected collapse observed during the 1990s in the cycle of this insect, which was regularly outbreaking every 8-10 years in the Alps for hundreds of years (Battisti 2008). Further increase in temperature is predicted to induce long-term perturbations in the Zeiraphera larch system, with a possible induced shift of intense outbreak areas towards higher altitudes (Büntgen et al. 2009).

However, disrupted synchrony will lead to selection, and a response in phenology to this selection might lead to species genetically adapting to their changing environment. In the case of the winter moth cited above, Van Asch et al. (2007) show that egg-hatching reaction norms are heritable and that sufficient genetic variation exists to predict a rapid response to selection, leading to a restoration of synchrony of egg hatch with oak bud opening.

POSITIVE EFFECTS ON WINTER SURVIVAL AND CONSEQUENCES ON THE POTENTIAL LIMITS OF SPECIES RANGE 
Under temperate latitudes, low temperature is usually a key factor constraining the range expansion through minimal thresholds required for the insect survival and development at the different stages (egg, larva, pupa and adult). For instance, the lower lethal temperature for the southern pine beetle Dendroctonus frontalis Zimmermann has been estimated at $-16{ }^{\circ} \mathrm{C}$. Therefore, lower winter temperatures are limiting the beetle's northern distribution (Ungerer et al. 1999). In the past, beetle presence in southern USA effectively matched the areas where the probability of reaching this lethal temperature was low. However, since 2000, outbreaks have been observed at northern latitudes, where their probability was highly unlikely, first in New Jersey and Ohio (2001), and then in Maryland (2005). Trần et al. (2007) show that these new outbreaks are directly related to a latitudinal shift in winter isotherms. Similarly, the unprecedented outbreak of mountain pine beetle Dendroctonus ponderosae Hopkins, currently affecting over 10.1 million hectares of lodgepole pine forests (Pinus contorta Dougl.) in British Columbia, Canada, partly relies on the occurrence of warmer winters. Warmer winters allow better beetle survival during overwintering (Kurz et al. 2008). A slight difference in cold tolerance could also explain the difference in the outbreak range expansion of 2 cyclic geometric moths, the winter moth, Operophtera brumata, and the autumnal moth, Epirrita autumnata (Borkhausen), in northern Scandinavia, the winter moth showing a larger decrease in egg mortality with increasing temperatures (Jepsen et al. 2008).

One of the best documented, most striking examples of the effect of climate warming on the release of thermal thresholds constraining species distribution is the pine processionary moth Thaumetopoea pityocampa (Den. \& Schiff.). Originally Mediterranean, this insect is currently expanding its range distribution towards higher latitudes and altitudes (Battisti et al. 2005). This range expansion is clearly associated with better winter survival and enhanced feeding activity. Larval development occurs during winter and is limited by both a lethal temperature $\left(-16{ }^{\circ} \mathrm{C}\right.$; Battisti et al. 2005) and temperature thresholds allowing the nocturnal feeding uptake; that is, a daytime temperature higher than $9{ }^{\circ} \mathrm{C}$ within the larval nest followed by a nighttime temperature higher than $0{ }^{\circ} \mathrm{C}$ in the air (Battisti et al. 2005). If 1 of the 2 latter temperature conditions is not 
satisfied, larvae starve in the nest and their survival and performances are reduced (Buffo et al. 2007). Climatic models based on these thresholds revealed the occurrence until the mid-1990s of a highly unfavorable area in the south of the Paris Basin (France), which constituted a barrier to latitudinal insect expansion. With the warming up observed in the area since 1996, the moth is no longer limited by unfavorable larval feeding conditions. It has succeeded in crossing this area and is expanding its range distribution northwards by $5.6 \mathrm{~km}$ per year (Robinet et al. 2007).

Thus, climate change might remove/relocate barriers that control spread and so allow for an expansion in areas where the species were previously kept in check by climatic factors (Walther et al. 2002; Battisti et al. 2005).

\section{NATURAL DISPERSAL AND ACTUAL RANGE MODIFICATIONS WITH GLOBAL}

\section{WARMING}

Although climate warming could allow a species to extend its range, it might not be able to shift with its climatic envelope because of limited dispersal capabilities (Thomas et al. 2004). Increased temperatures might extend the flying period of insects and thereby enable them to become dispersed over greater distances (Ott 2008). For instance, migration patterns of the silver Y moth Autographa gamma (L.) (Lepidoptera: Noctuidae) to Britain are largely influenced by the changes in temperatures and rainfall in its overwintering sites of North Africa (Chapman et al. 2008). Following the heat wave that occurred in Europe during the summer of 2003, the distribution of the pine processionary moth has considerably extended at higher elevations in the Italian Alps. Battisti et al. (2006) show that the nights above the threshold temperature for flight take-off $\left(14^{\circ} \mathrm{C}\right)$ were over 5 times more frequent, and considerably warmer, at the range limit in 2003 than in an average year. Therefore, a larger proportion of female moths was allowed to disperse over long distances.

Indeed, a number of species belonging to different groups such as beetles, butterflies, dragonflies and grasshoppers have moved northwards and to higher elevations during the past 30 years (Hickling et al. 2006). Although most studies provide evidence of expansion, few species 
have been reported to show no change in distribution or even a contraction of their southern range with global warming (see Menéndez 2007 for a review). Southerly distributed butterfly species in Britain tend to expand their range distribution northwards, whereas the most northerly distributed species have little opportunity to expand northward and most of them will probably decline (Hill et al. 2002). Even though a large variability is observed among species, Parmesan et al. (1999) show that the northern limit of European butterflies tends to shift northwards, whereas the southern limit remains stable in most cases. As an example for possible range contraction in the future, the nun moth Lymantria monacha (L.) is likely to suffer from too large an increase in temperatures because of negative effects on diapause termination (Vanhanen et al. 2007).

More generally, assuming that the growth period takes place during summer and the single diapause during winter, Bale et al. (2002) suggest that changes in the range distribution of the insect species could be roughly determined by a combination between the growth rate (slow or fast) and diapause requirement. They predict that: (i) fast growing, non-diapausing species are likely to be multivoltine and expand their ranges (e.g. anholocyclic aphids); (ii) fast growing species with a temperature-dependent diapause might contract their ranges (e.g. the lepidopterans Inachis io [L.], Aglais urticae [L.] and Saturnia pavonia [L.]); and (iii) slow-growing species with a temperaturedependent diapause will not maintain their ranges and will probably decline (e.g. Lasiocampa quercus callunae Palmer).

Even when a species is actually able to expand its distribution, another factor might affect its establishment. Indeed, when some individuals disperse into new areas, they are generally at low densities. If the population falls below a minimum population density, called the Allee threshold, it will likely go extinct naturally (Lande 1993; Liebhold \& Tobin 2008). Many factors may generate Allee effects, such as a decrease in cooperation to find resources and avoid natural enemies, an increase of inbreeding and an increase of reproduction difficulties at low population density. In this regard, climatic factors might play an important role if they can increase the per capita reproductive output for any given population density. Invasive species with high mobility could more easily 
follow the shift of the climate envelope and have the greatest potential for rapid expansion. However, in the case of Allee effects, they might fail to expand when they move to a large favorable area because of the dissemination of the population in space, and the decrease in the population density (Roques et al. 2008). The population growth rate could increase with climate change; so, Allee effects would not occur anymore and species with high dispersal capabilities could successfully invade new territories.

\section{GLOBAL WARMING AND HUMAN-ASSISTED DISPERSAL, A NEW POSSIBILITY FOR SUCCESSFUL LONG-DISTANCE JUMPS AND INVASIONS}

Long-distance jumps far beyond the natural range of an insect might not permit an establishment in most species because of the high probability of encountering unfavorable climatic conditions in the new area. However, climate warming has undeniably contributed to increase the probability of establishment of these long-distance dispersers beyond their natural distribution. An isolated but large colony of the pine processionary moth has recently been recorded in north-eastern France (Alsace), approximately $190 \mathrm{~km}$ from the current northern limits of the range (French Forest Health Department, pers. comm.). With respect to the colony size, it is likely that the colony funders had been introduced by the early 2000s, probably as moth pupae carried with the soil accompanying large pine trees translocated from southern areas as ornamentals. A retrospective analysis of the climatic conditions having occurred in the area showed that moth larvae had quite a null probability of surviving if introduced during the $1990 \mathrm{~s}$ because of winter temperatures frequently under the lethal threshold. The warming up of the area since 2000 largely modified these conditions, resulting in a high probability of establishment of self-sustaining moth populations once accidentally introduced by humans (Robinet et al. 2010). Other Mediterranean insects, such as the praying mantis Mantis religiosa (L.) and the bush cricket Meconema meridionale A. Costa, are expanding their native range in southern Germany, but they are also found further north, far away 
from their natural range, and these populations are also considered to be the result of accidental transport by humans (Ott 2008).

More generally, these observations apply to exotic alien species originating from regions warmer than the invaded one. Until recently, species introduced from warmer regions to temperate areas have been constrained by growing seasons that are too short, which has prevented several species from becoming naturalized. This is changing. Global warming is likely to provide new opportunities for introductions to areas where introduced species were not able to survive previously (Walther et al. 2009; Roques 2010). For instance, more than 400 out of the 1315 nonnative insect species already established in Europe originated from areas with subtropical and/or tropical climates and appeared thus capable of surviving under European winter conditions, at least locally (e.g. along the Mediterranean coast, Roques et al. 2009). The recent arrival and establishment of several tropical species associated with palms is illustrative of this process. Since 1993, 31 palm pests have been recorded, among them a Castniidae moth from South America, Paysandisia archon (Burmeister), and the red palm weevil, Rhynchophorus ferrugineus (Olivier), from Melanesia. These 2 species stayed for some time in the western part of the Mediterranean basin but largely expanded from 2004 to 2007 to colonize the whole Mediterranean region (Roques 2010). More generally, the colonization of palms, eucalyptus and tropical legume trees planted in Europe significantly increased during the period 2000-2007 through the establishment of hostspecific exotic insects, whereas that of broad-leaved trees remained stable and that of conifers decreased (Roques 2010). Former greenhouse inhabitants, such as 3 exotic scale species, Diaspidiotus distinctus (Leonardi), Coccus hesperidum L. and Icerya purchasi (Maskell), have also recently been found outdoors in Switzerland (Kenis 2006). Similarly, non-native biological control agents of greenhouse pests have started to establish outside the greenhouse environment, such as the predatory bug Macrolophus caliginosus Wagner (Hart et al. 2002) and the predatory mite Neoseiulus californicus McGregor (Hatherly et al. 2005) in the UK. There is also evidence of a 
strong association between patterns of the emergence of invasive gypsy moth Lymantria dispar L. and annual climatic suitability in Ontario (Canada) (Régnière et al. 2009).

Expansion of native species or spread of alien insects into new areas with global warming is likely to cause serious economic or ecological hazards, affecting species inhabiting invaded areas. For example, 3 springtail species accidentally introduced into the Marion island perform better than indigenous springtails in the warmer and dryer climate that this sub-Antarctic island is presently facing (Chown et al. 2007; Slabber et al. 2007). The carabid beetle Oopterus soledadinus (Guérin) was accidentally introduced into the Kerguelen Islands (sub-Antarctic) from the Falklands at the beginning of the 20th century. However, it was not before the second half of the century that it started to spread, possibly due to increased temperature and lower precipitation (Chevrier et al. 1997). It has now invaded most regions and has become so abundant that it is threatening the native fauna. The southern green stink bug Nezara viridula (L.), formerly a sub-tropical species, has been expanding its range northward in temperate regions of Japan and Europe since the 1960s (Musolin 2007), probably because of reduced winter mortality resulting from milder winters. In the newlyinvaded regions in Japan, $N$. viridula has become a major pest, outcompeting the indigenous $N$. antennata Scott (Tougou et al. 2009).

\section{SUGGESTIONS FOR FUTURE RESEARCH}

In most cases, the effects of climate change have been considered with regard to an increasing temperature mean. However, even if such a variable can be more easily manipulated for comparisons, its single use is likely to result in a number of biases. First, as previously mentioned, other important factors should be considered, including solar radiation, humidity, rainfall and levels of greenhouse gazes. For instance, the establishment of the invasive Asian mosquito Aedes albopictus (Skuse) depends on temperature but also on photoperiod, humidity and rainfall (Eritja et al. 2005). Even though testing the effect of one factor in laboratory conditions is relatively easy, testing the effects of numerous factor combinations in the field is extremely complex, and 
contradictory results are likely to appear (see Newman 2005 for the effects of an increase in $\mathrm{CO}_{2}$ level). Investigating the possible synergistic effects between temperature and other potential driving factors is a real challenge for the future, especially through the development of large- scale field experiments.

Second, changes in temperature means do not completely reflect the changes in maximums and minimums that actually affect survival and development (e.g. considering higher and lower lethal temperatures for a given development stage). The temperature mean variability could have important effects in itself (Easterling et al. 2000; Walther et al. 2002). Insect populations are not facing a mean annual temperature but a year-to-year and day-to-day fluctuation of the weather conditions. From this point of view, an increase in temperature will not have the same significance when occurring in winter, spring or summer, and could even result in contradictory effects on insect populations. Moreover, the role of stochastic climatic anomalies is thus underestimated. Some species have an inherent ability to respond positively and permanently to rapid changes or fluctuations in climate. The pine processionary moth again provides a striking example for both these questions. Whereas the warm winters during 2000-2003 triggered larvae survival in the newly-colonized areas of the Paris Basin, the heat wave of summer 2003 killed a large part of the population in the same area (Robinet et al. 2010). Contradictorily, the high temperatures observed in the same summer 2003 positively resulted in a significant altitudinal shift of the moth in the Italian Alps (Battisti et al. 2006). Indeed, the moths were not at the same development stages in the 2 sites when the heat wave occurred. Adults are emerging earlier in the Paris Basin, and, therefore, extremely high, lethal temperatures affected egg-masses and first-instar larvae while these warm temperatures stimulated adult flight in the Alps. Similar adverse effects of warming according to season have been observed in the southern green stink bug, Nezara viridula. Although warming is strongly enhancing survival of adults in winter and accelerating development in autumn, it is negatively affecting nymphal development during summer (Musolin et al. 2010). This complexity has to be taken into account while attempting to predict the potential effects of global warming. As 
Battisti et al. (2006) point out, an emphasis on long-term slow change in climatic variables might be insufficient in predicting species' responses to climate change, especially in light of the forecast rise in stochasticity of global climate dynamics.

Third, climate change affects the entire ecosystem, including host plants, competitors and natural enemies, but the responses probably differ among species and guilds, altering their interactions and the composition of the ecosystem (Petchey et al. 1999; Stenseth et al. 2002; Walther et al. 2002; Visser \& Both 2005). As argued by Harrington et al. (2001), the concentration of studies on species obviously profiting from climate change might easily lead to the wrong conclusion that all insect pests will gain in importance. Altered environmental conditions will certainly bring about ambiguous consequences, involving positive, indifferent as well as negative responses of species. The disturbance of coevolved relationships might, for instance, be beneficial for the affected host plant, the herbivore species or neither of them. Some theoretical models have already been proposed to predict the changes in ecosystems (Berggren et al. 2009). It seems that the sensitivity to temperature could possibly increase with trophic level, but further investigation is needed to understand more deeply these changes in the field. For instance, no general pattern has emerged from the limited number of studies regarding the response of natural enemies to global warming. According to Roy et al. (2004), parasitoids and predators might simply respond to the population sizes and preferences of their hosts. However, some other case studies tend to show differential responses between natural enemies and insect hosts. The effectiveness of certain predators, such as ladybeetles, would increase in a warmer environment (Cannon 1998), and synchrony between parasitoids and host insects might be favored (Parmesan 2006). In contrast, climate warming would allow the host to better escape from natural enemies in the spruce budmoth, Choristoneura fumiferana (Clemens) (Fleming \& Candau 1998), and from egg parasitoids in the expansion area of the pine processionary moth (Roques et al. 2005). Moreover, the interactions of these 2 trophic levels with the host plant have to be considered in order to obtain a correct picture. For example, Rouault et al. (2006) predict that reduced palatability of host tissue following drought 
might lead to decreased development rates in defoliators and, subsequently, increase the duration of exposure to parasitoids. The development of more studies at the whole community level, that consider more than a single species, is of outstanding importance for a better understanding of the interactions between the different factors related to climate change.

Fourth, understanding the adaptive processes and the underlying genetic changes is essential for predicting long-term insect responses to climate change (Menéndez 2007). Sampling for genetic analysis should also be included in the collection scheme to investigate possible evolutionary changes. Bale et al. (2002) hypothesize that insect species can potentially respond to climate change through phenotypic flexibility or rapid evolutionary (genetic) responses to strong selection. For instance, the winter moth cited above was assumed to rapidly restore the disrupted synchrony with host plant development. More generally, when a species moves polewards as a consequence of climate warming, the day length becomes notably shorter. The northern populations of the pitcher plant mosquito, Wyeomyia smithii (Coq.), increased the length of its growing season and postponed the timing of its hibernation to counterbalance the shorter photoperiod (Bradshaw \& Holzapfel 2008). Its critical photoperiod varies along the climatic gradient in North America, and this adaptation is actually driven by genetic features (Mathias et al. 2006).

Finally, in order to understand the mechanisms governing the response to climate change, it seems important to consider only a few relevant case studies among the numerous species that can be studied. For this purpose, it is important to keep on collecting data on the long term and update the distribution of the study species. Unfortunately, there is still little information on the precise distribution of most species in the world, and for the most well-known species, historical distribution maps are not always suitable or reliable for such studies. Therefore, we should improve technical methods to collect such data and obtain a good database to serve as a baseline for future studies. 


\section{ACKNOWLEDGMENTS}

We greatly acknowledge support for this work from the FP7 EU project PRATIQUE KBBE-2007212459 (Enhancements of pest risk analysis techniques; Baker et al. 2009; https://secure.fera.defra.gov.uk/pratique/index.cfm), the FP7 EU project BACCARA KBBE-2008 (Biodiversity and climate change, a risk Analysis; http://www.baccara-project.eu/), the URTICLIM project “Anticipation des effets du changement climatique sur l'impact écologique et sanitaire d'insectes forestiers urticants" of the French Agence Nationale de la Recherche (ANR 07BDIV 013), and the FAST project (Analyse des évolutions régionalisées de la forêt métropolitaine face aux aléas climatiques et biotiques, avec des scénarios de gestion forestière d'atténuation et d'adaptation) of the French Ministry of Ecology and Sustainable Development. This work was also supported by the ISZS international research program Biological Consequences of Global Change (BCGC) which is sponsored by Bureau of International Coorperation, Chinese Academy of Sciences (GJHZ200810).

\section{REFERENCES}

Andrewartha HG, Birch LC (1984). The ecological Web: More on the Distribution and Abundance of Animals. University of Chicago Press, Chicago.

Asshoff R, Hättenschwiler S (2006). Changes in needle quality and larch bud moth performance in response to $\mathrm{CO}_{2}$ enrichment and defoliation of treeline larches. Ecological Entomology 31, 8490.

Ayres MP, Lombardero MJ (2000). Assessing the consequences of global change for forest disturbance from herbivores and pathogens. The Science of the Total Environment 262, 263-86.

Baker RHA, Battisti A, Bremmer J et al. (2009). PRATIQUE: A research project to enhance pest risk analysis techniques in the European Union. Bulletin OEPP/EPPO Bulletin 39, 97-3.

Bale JS, Masters GJ, Hodkinson ID et al. (2002). Herbivory in global climate change research: Direct effects of rising temperature on insect herbivores. Global Change Biology 8, 1-16. 
Battisti A (2008). Forests and climate change - lessons from insects. iForest 1, 1-5.

Battisti A, Stastny M, Netherer S et al. (2005). Expansion of geographic range in the pine processionary moth caused by increased winter temperatures. Ecological Applications 15, 208496.

Battisti A, Stastny M, Buffo E, Larsson S (2006). A rapid altitudinal range expansion in the pine processionary moth produced by the 2003 climatic anomaly. Global Change Biology 12, 662-71. Beck SD (1983). Insect thermoperiodism. Annual Review of Entomology 28, 91-108.

Berg EE, Henry JD, Fastie CL, De Volder AD, Matsuoka SM (2006). Spruce beetle outbreaks on the Kenai Peninsula, Alaska, and Kluane National Park and Reserve, Yukon Territory: Relationship to summer temperatures and regional differences in disturbance regimes. Forest Ecology and Management 227, 219-32.

Berggren A, Björkman C, Bylund H, Ayres MP (2009). The distribution and abundance of animal populations in a climate of uncertainty. Oikos 118, 1121-6.

Bidart-Bouzat MG, Imeh-Nathaniel A (2008). Global change effects on plant chemical defenses against insect herbivores. Journal of Integrative Plant Biology 50, 1339-54.

Bradshaw WE, Holzapfel CM (2008). Genetic response to rapid climate change: It's seasonal timing that matters. Molecular Ecology 17, 157-66.

Buffo E, Battisti A, Stastny M, Larsson S (2007). Temperature as a predictor of survival of the pine processionary moth in the Italian Alps. Agricultural and Forest Entomology 9, 65-72.

Büntgen U, Frank D, Liebhold A et al. (2009). Three centuries of insect outbreaks across the European Alps. New Phytologist 182, 929-41.

Cannon RJC (1998). The implications of predicted climate change in the UK, with emphasis on non-indigenous species. Global Change Biology 4, 785-96.

Chapman JW, Reynolds DR, Smith AD, Riley JR, Pedgley DE, Woiwod IP (2008). Wind selection and drift compensation optimize migratory pathways in a high-flying moth. Current Biology 18, $514-8$. 
Chevrier M, Vernon P, Frenot Y (1997). Potential effects of two alien insects on a subantarctic wingless fly in the Kerguelen Islands. In: Battaglia B, Valencia J, Walton DWH, eds. Antarctic Communities: Species, Structure and Survival. Cambridge University Press, Cambridge, UK, pp. 424-31.

Chown SL, Slabber S, McGeoch MA, Janion C, Leinaas HP (2007). Phenotypic plasticity mediates climate change responses among invasive and indigenous arthropods. Proceedings Royal Society London B 274, 2531-7.

Crozier L (2003). Winter warming facilitates range expansion: Cold tolerance of the butterfly. Atalopedes campestris Oecologia 135, 648-56.

DeLucia EH, Casteel CL, Nabity PD, O’Neill BF (2008). Insects take a bigger bite out of plants in a warmer, higher carbon dioxide world. PNAS 105, 1781-2.

Deutsch CA, Tewksbury JJ, Huey RB et al. (2008). Impacts of climate warming on terrestrial ectotherms across latitude. PNAS 105, 6668-72.

Dixon AFG (2003). Climate change and phenological asynchrony. Ecological Entomology 28, 38081.

Easterling DR, Meehl GA, Parmesan C, Changnon SA, Karl TR, Mearns LO (2000). Climate extremes: Observations, modeling, and impacts. Science 289, 2068-74.

Eritja R, Escosa R, Lucientes J et al. (2005). Worldwide invasion of vector mosquitoes: Present European distribution and challenges for Spain. Biological Invasions 7, 87-97

Esper J, Büntgen U, Franck DC, Nievergelt D, Liebhold A (2007). 1200 years of regular outbreaks in alpine insects. Proceedings of the Royal Society of London B 274, 671-9.

European Environment Agency (2008). Impacts of Europe's changing climate. European Environment Agency report EEA Briefing 3/2008. [Cited 28 Feb 2010.] Available from URL: http://www.eea.europa.eu/publications/briefing_2008_3 
Fleming RA, Candau JN (1998). Influences of climatic change on some ecological processes of an insect outbreak system in Canada's boreal forests and the implications for biodiversity. Environmental Monitoring and Assessment 49, 235-49.

Forister ML, Shapiro AM (2003). Climatic trends and advancing spring flight of butterflies in lowland California. Global Change Biology 9, 1130-35.

Gomi T, Nagasaka M, Fukuda T, Hagihara H (2007). Shifting of the life cycle and life-history traits of the fall webworm in relation to climate change. Entomologia Experimentalis Applicata 125, $179-84$.

Gordo O, Sanz JJ (2005). Phenology and climate change: A long-term study in a Mediterranean locality. Oecologia 146, 484-95.

Hance T, van Baaren J, Vernon P, Boivin G (2007). Impact of Extreme Temperatures on Parasitoids in a Climate Change Perspective. Annual Review of Entomology 52, 107-26.

Harrington R, Fleming RA, Woiwod IP (2001). Climate change impacts on insect management and conservation in temperate regions: Can they be predicted? Agricultural and Forest Entomology $3,233-40$.

Harrington R, Clark SJ, Welhalm SJ et al. (2007). Environmental change and the phenology of European aphids. Global Change Biology 13, 1550-64.

Hart AJ, Tullett AG, Bale JS, Walters KFA (2002). Effects of temperature on the establishment potential in the UK of the non-native glasshouse biocontrol agent. Macrolophus caliginosus. Physiological Entomology 27, 112-23.

Hatherly IS, Hart AJ, Tullett AG, Bale JS (2005). Use of thermal data as a screen for the establishment potential of non-native biological control agents in the UK. BioControl 50, 68798.

Helmuth B (2009). From cells to coastlines: How can we use physiology to forecast the impacts of climate change? Journal of Experimental Biology 212, 753-60. 
Herms DA, Mattson WJ (1992). The dilemma of plants: To grow or defend. Quarterly Review of Biology 67, 283-335.

Hickling R, Roy DB, Hill JK, Fox R, Thomas CD (2006). The distributions of a wide range of taxonomic groups are expanding polewards. Global Change Biology 12, 450-55.

Hill JK, Thomas CD, Fox R et al. (2002). Responses of butterflies to twentieth century climate warming: Implications for future ranges. Proceedings of the Royal Society of London B 269, $2163-71$.

Hughes L (2000). Biological consequences of global warming: Is the signal already apparent? Trends in Ecology and Evolution 15, 56-61.

Hunter D (2001). Effects of elevated atmospheric carbon dioxide on insect-plant interactions. Agricultural and Forest Entomology 3, 153-9.

Jepsen JU, Hagen SB, Ims RA, Yoccoz NG (2008). Climate change and outbreaks of the geometrids Operophtera brumata and Epirrita autumnata in subarctic birch forest: Evidence of a recent outbreak range expansion. Journal of Animal Ecology 77, 257-64.

Jönsson AM, Appelberg G, Harding S, Bärring L (2009). Spatio-temporal impact of climate change on the activity and voltinism of the spruce bark beetle, Ips typographus. Global Change Biology 15, 486-99.

Kenis M (2006). Insects-Insecta. In: Wittenberg R, ed. Invasive Alien Species in Switzerland: An inventory of Alien Species and their Threat to Biodiversity and Economy in Switzerland. Swiss Confederation - Federal Office for the Environment Environmental Studies 29/6, pp. 131-211.

Kiritani K (2006). Predicting impacts of global warming on population dynamics and distribution of arthropods in Japan. Population Ecology 48, 5-12.

Kurz WA, Dymond CC, Stinson G et al. (2008). Mountain pine beetle and forest carbon feedback to climate change. Nature $452,987-90$.

Lande R (1993). Risks of population extinction from demographic and environmental stochasticity and random catastrophes. American Naturalist 142, 911-27. 
Lange H, Økland B, Krokene P (2006). Thresholds in the life cycle of the spruce bark beetle under climate change. Interjournal for Complex Systems 1648, 1-10.

Lawler JJ, Shafer SL, White D et al. (2009). Projected climate-induced faunal change in the Western Hemisphere. Ecology 90, 588-97.

Liebhold AM, Tobin PC (2008). Population ecology of insect invasions and their management. Annual Review of Entomology 53, 387-408.

Logan JA, Regnière J, Powell JA (2003). Assessing the impacts of global warming on forest pest dynamics. Frontiers in Ecology and the Environment 1, 130-7.

Mathias D, Reed K, Bradshaw WE, Holzapfel CM (2006). Evolutionary divergence of circadian and photoperiodic phenotypes in the pitcher-plant mosquito. Wyeomyia smithii. Journal of Biological Rhythms 21, 132-9.

Meehl GA, Stocker TF, Collins WD et al. (2007). Global climate projections. In: Solomon S et al., eds. Climate Change 2007: The Physical Science Basis. Contribution of Working Group I to the Fourth Assessment Report of the Intergovernmental Panel on Climate Change. Cambridge University Press, Cambridge, pp. 747-845.

Menéndez R (2007). How are insects responding to global warming? Tijdschrift voor Entomologie $150,355-65$.

Messenger PS (1959). Bioclimatic studies with insects. Annual Review of Entomology 4, 183-206.

Musolin DL (2007). Insects in a warmer world: Ecological, physiological and life-history responses of true bugs (Heteroptera) to climate change. Global Change Biology 13, 1565-85

Musolin DL, Tougou D, Fujisaki K (2010). Too hot to handle? Phenological and life-history responses to simulated climate change of the southern green stink bug Nezara viridula (Heteroptera: Pentatomidae). Global Change Biology 16, 37-8.

Netherer S, Schopf A (2010). Potential effects of climate change on insect herbivores in European forests-General aspects and the pine processionary moth as specific example. Forest Ecology and Management 259, 831-8. 
Newman JA (2005). Climate change and the fate of cereal aphids in Southern Britain. Global Change Biology 11, 940-44.

Ott J, ed (2008). Monitoring climate change with dragonflies. Series Faunistica 81. Pensoft, Sofia. Parmesan C (2006). Ecological and evolutionary responses to recent climate change. Annual Review of Ecology, Evolution, and Systematics 37, 637-69.

Parmesan C (2007). Influences of species, latitudes and methodologies on estimates of phenological response to global warming. Global Change Biology 13, 1860-72.

Parmesan C, Yohe G (2003). A globally coherent fingerprint of climate change impacts across natural systems. Nature 421, 37-42.

Parmesan C, Ryrholm N, Stefanescu C et al. (1999). Poleward shifts in geographical ranges of butterfly species associated with regional warming. Nature 399, 579-83.

Petchey OL, McPhearson PT, Casey TM, Morin PJ (1999). Environmental warming alters foodweb structure and ecosystem function. Nature 402, 69-72.

Price PW, Bouton CE, Gross P, McPheron BA, Thompson JN, Weis AE (1980). Interactions among 3 trophic levels: Influence of plants on interactions between insect herbivores and natural enemies. Annual Review of Ecology and Systematics 11, 41-65.

Régnière J, Nealis V, Porter K (2009). Climate suitability and management of the gypsy moth invasion into Canada. Biological Invasions 11, 135-48.

Robinet C, Baier P, Pennerstorfer J, Schopf A, Roques A (2007). Modelling the effects of climate change on the potential feeding activity of Thaumetopoea pityocampa (Den \& Schiff) (Lep, Notodontidae) in France. Global Ecology and Biogeography 16, 460-71.

Robinet C, Rousselet J, Goussard F, Roques A (2010). Modelling the range expansion with global warming of an urticating moth: a case study from France. In: Settele J, ed. Atlas of Biodiversity Risks - From Europe to the Globe, From Stories to Maps. Pensoft, Sofia, 86-87. 
Roques A (2010). Alien forest insects in a warmer world and a globalized economy: Impacts of changes in trade, tourism and climate on forest biosecurity: New Zealand Journal of Forestry $\mathbf{4 0}$ (suppl), 77-94.

Roques A, Rousselet J, Robinet C, Goussard F, Battisti A (2005). Range expansion of the pine processionary moth in Europe I-Mechanisms underlying PPM expansion in France in relation to global warming. In: Gottschalk KW, ed. Proceedings of the 16th US Department of Agriculture Interagency Research Forum on Gypsy Moth and Other Invasive Species, 2005. USDA Forest Service, General Technical Report NE-337, pp. 71-2.

Roques L, Roques A, Berestycki H, Kretzschmar A (2008). Population facing climate change: Joint influences of Allee effects and environmental boundary geometry. Population Ecology 50, 21525.

Roques A, Rabitsch W, Rasplus J-Y, Lopez-Vaamonde C, Nentwig W, Kenis M (2009). Alien terrestrial invertebrates of Europe In: DAISIE, ed. Handbook of alien species in Europe. Springer Science+ Business Media BV, Knoxville, pp. 63-79.

Rosenzweig C, Casassa G, Karoly DJ et al. (2007) Assessment of observed changes and responses in natural and managed systems. In: Parry ML et al., eds. Climate Change 2007: Impacts, Adaptation and Vulnerability. Contribution of Working Group II to the Fourth Assessment Report of the Intergovernmental Panel on Climate Change. Cambridge University Press, Cambridge, pp. $79-131$.

Rouault G, Candau JN, Lieutier F, Nageleisen LM, Martin JC, Warzée N (2006). Effects of drought and heat on forest insect populations in relation to the 2003 drought in Western Europe. Annals of Forest Science 63, 613-24.

Roy DB, Sparks TH (2000). Phenology of British butterflies and climate change. Global Change Biology 6, 407-16.

Roy B, Güsewell S, Harte J (2004). Response of plant pathogens and herbivores to a warming experiment. Ecology 85, 2570-81. 
Slabber S, Worland MR, Leinaas HP, Chown SL (2007). Acclimation effects on thermal tolerances of springtails from sub-Antarctic Marion Island: Indigenous and invasive species. Journal of Insect Physiology 53, 113-25.

Stefanescu C, Peñuelas J, Filella I (2003). Effects of climatic change on the phenology of butterflies in the northwest Mediterranean Basin. Global Change Biology 9, 1494-506.

Stenseth NC, Mysterud A, Ottersen G, Hurrell JW, Chan KS, Lima M (2002). Ecological effects of climate fluctuations. Science 297, 1292-6.

Stige LC, Chan K-S, Zhang Z, Franck D, Stenseth NC (2007). Thousand-year-long Chinese time series reveals climatic forcing of decadal locust dynamics. PNAS 104, 16188-93.

Stireman JO, Dyer LA, Janzen DH et al. (2005). Climatic unpredictability and parasitism of caterpillars: Implications of global warming. PNAS 102, 17384-7.

Thomas CD, Cameron A, Green RE et al. (2004). Extinction risk from climate change. Nature 427, $145-8$.

Tougou D, Musolin DL, Fujisaki K (2009). Some like it hot! Rapid climate change promotes changes in distribution ranges of Nezara viridula and Nezara antennata in Japan Entomologia Experimentalis and Applicata. 130, 249-58.

Trần JK, Ylioja T, Billings R, Régnière J, Ayres MP (2007). Impact of minimum winter temperatures on the population dynamics of Dendroctonus frontalis. Ecological Applications 17, 882-99.

Trenberth KE, Jones PD, Ambenje P et al. (2007). Observations: Surface and Atmospheric Climate Change. In: Solomon S et al., eds. Climate Change 2007: The Physical Science Basis. Contribution of Working Group I to the Fourth Assessment Report of the Intergovernmental Panel on Climate Change. Cambridge University Press, Cambridge, pp. 235-336.

Ungerer MJ, Ayres MP, Lombardero MJ (1999). Climate and the northern distribution limits of Dendroctonus frontalis Zimmermann (Coleoptera: Scolytidae). Journal of Biogeography 26, $1133-45$. 
Van Asch M, Visser ME (2007). Phenology of forest caterpillars and their host trees: The importance of synchrony. Annual Review of Entomology 52, 37-55.

Van Asch M, van Tienderen PH, Holleman LJM, Visser ME (2007). Predicting adaptation of phenology in response to climate change, an insect herbivore example. Global Change Biology 13, 1596-604.

Vanhanen H, Veteli TO, Pailvinen S, Kellomaki S, Niemala P (2007). Climate change and range shifts in two insect defoliators: Gypsy moth and nun moth - A model study. Silva Fennica 41, $621-38$.

Virtanen T, Neuvonen S (1999). Climate change and macrolepidopteran biodiversity in Finland. Chemosphere - Global Change Science 1, 439-8.

Visser ME, Both C (2005). Shifts in phenology due to global climate change: The need for a yardstick. Proceedings of the Royal Society of London B 272, 2561-9.

Walther G-R, Burga CA, Edwards PJ (2001). "Fingerprints" of Climate Change: Adapted Behaviour and Shifting Species Ranges. Kluwer Academic/Plenum Publishers, New York.

Walther GR, Post E, Convey P et al. (2002). Ecological responses to recent climate change. Nature 416, 389-95.

Walther GR, Roques A, Hulme PE et al. (2009). Alien species in a warmer world: Risks and opportunities. Trends in Ecology and Evolution 24, 686-93.

Wolf A, Kozlov MV, Callaghan TV (2008). Impact of non-outbreak insect damage on vegetation in northern Europe will be greater than expected during a changing climate. Climatic Change 87, 91-106.

Zhang Z, Cazelles B, Tian H, Stige LC, Bräuning A, Stenseth NC (2009). Periodic temperatureassociated drought/flood drives locust plagues in China. Proceedings of the Royal Society of London B 276, 823-31. 